\title{
Rancangan Undang-Undang Ketahanan Keluarga Dalam Perspektif Sosiologi Gender
}

\author{
Aulia Nursyifa a,1 \\ ${ }^{a}$ Fakultas Keguruan dan Ilmu Pendidikan, Universitas Pamulang \\ laulianursyifa@unpam.ac.id
}

Naskah diterima: 28 Februari 2020, direvisi: 18 Maret 2020, disetujui: 25 Maret 2020

\begin{abstract}
Abstrak
Rancangan Undang-Undang (RUU) Ketahanan Keluarga bertujuan untuk memperkuat ketahanan keluarga di Indonesia. Namun dalam implementasi RUU ketahanan keluarga menjadi polemik di kalangan masyarakat. Salah satu permasalahan pada RUU ketahanan keluarga terkait dengan ketidakadilan gender, terutama terkait dengan peran dan fungsi perempuan dalam keluarga. Artikel ini bertujuan untuk menganalisis RUU Ketahanan Keluarga dalam perspektif sosiologi gender. Penulisan artikel ini menggunakan metode kajian literatur yang berasal dari buku, jurnal, dokumen lain yang relevan. Hasil kajian ini menunjukkan bahwa Rancangan Undang-Undang ketahanan keluarga mengandung pasal yang dapat menimbulkan kotroversi di masyarakat terutama tentang hak dan kewajiban suami maupun istri yang dapat menimbulkan ketidakadilan gender, menempati perempuan memiliki kewajiban bekerja pada ranah domestik. Ketahanan keluarga memiliki tujuan baik untuk memperkuat ketahanan keluarga sebagai upaya mewujudkan ketahanan bangsa, namun perlu dikaji lebih mendalam tentang pasal-pasal yang ada di dalam RUU ketahanan keluarga agar tetap mengedepankan keadilan gender di Indonesia.
\end{abstract}

Kata-kata kunci: Rancangan Undang-Undang; Ketahanan Keluarga; Sosiologi Gender

\begin{abstract}
Family Resilience Bill aims to strengthen family resilience in Indonesia. But in the implementation of the family resilience bill became polemical among the community. One of the issues in the family resilience bill relates to gender injustice, especially when it comes to the roles and functions of women in families. This article aims to analyze the family defense bill in a gender sociological perspective. The writing of this article uses literary studies methods derived from books, journals, other relevant documents. The results of this study show that the Family Resilience Bill contains articles that can cause cotroversion in society, especially about the rights and obligations of husbands and wives that can lead to gender injustice, occupying women have an obligation to work in the domestic realm. Family resilience has a good goal to strengthen family resilience in order to realize the resilience of the nation, but it needs to be reviewed more deeply about the articles in the family resilience bill in order to continue promoting gender justice in Indonesia.
\end{abstract}

Keywords: Draft Law; Family Resilience; Gender Sociology 


\section{Pendahuluan}

Keluarga merupakan unit terkecil dalam kehidupan sosial yang memiliki peran sangat penting bagi kehidupan bangsa. Dari keluargalah akan lahir generasi-generasi unggul masa depan yang akan melanjutkan perjuangan bangsa. Keluarga memberikan harapan besar untuk memberikan solusi permasalahan sosial di masyarakat khususnya bagi generasi muda akan bahaya narkoba, pergaulan seks bebas, pornografi, tauran, dan berbagai penyimpangan sosial lainnya yang terjadi di masyarakat. Oleh karena itu, peran keluarga sangat penting untuk diperkuat bahkan diberikan payung hukum yang berfokus untuk memberikan ketahanan dalam keluarga.

Salah satu upaya dalam memperkuat ketahanan keluarga dengan adanya Rancangan Undang-Undang Ketahanan Keluarga yang digagas oleh Dewan Perwakilan Rakyat (DPR) RI dalam Program Legislasi Nasional (Prolegnas) tahun 2020 tentang Ketahanan Keluarga. RUU Ketahanan Keluarga dianggap menjadi solusi dari berbagai permasalahan yang muncul dalam keluarga. Sebagaimana termaktub dalam Pasal 1 Ayat 2 Rancangan Undang-Undang Ketahanan Keluarga yang berbunyi: "Ketahanan Keluarga merupakan kondisi dimana keluarga dapat mengelola sumber daya fisik maupun non fisik yang dimiliki serta dapat mengelola permasalah yang terjadi didalam kehidupan keluarga, dengan tujuan menjadi keluarga yang berkualitas serta menjadi pondasi utama dalam mewujudkan Ketahanan Nasional" (Dewan Perwakilan Rakyat, 2020).

Berdasarkan RUU Ketahanan Keluarga tersebut dapat menjadikan keluarga memiliki kemampuan dalam upaya mempertahankan kehidupannya baik dari segi kebutuhan fisik maupun non fisiknya, serta memiliki kemampuan dalam menyelesaikan permasalahan yang dihadapi baik permasalahan dari dalam maupun dari luar keluarganya. Dengan adanya RUU Ketahanan Keluarga menjadi solusi untuk memperkuat ketanahan nasional Bangsa Indonesia dari berbagai tantangan yang akan terjadi yang mengancam kehidupan bangsa. Oleh karena itu, tidak heran jika keluarga sebagai pondasi utama suatu bangsa. Sebagaimana yang diungkapkan oleh Margaret Mead (dalam Ihromi, 2009) keluarga merupakan lembaga yang dimiliki manusia yang paling kuat daya tahannya. Oleh karena itu, setiap manusia memiliki ikatan yang kuat dengan keluarganya, berbagai kebaikan yang dimiliki manusia bersumber dari panutan keluarganya karena keluargalah sebagai agen sosialisasi utama yang menghantarkan anak menjadi manusia dewasa yang dapat terjun di masyarakat.

Disatu sisi keluarga sebagai sumber kebahagian untuk menopang keunggulan bangsa, namun disatu sisi keluarga justru menjadi sumber ketidakadilan khususnya bagi perempuan dengan maraknya kasus Kekerasan Dalam Rumah Tangga (KDRT) dan perceraian. Sebagaimana dikutip dari Catatan Tahunan (CATAHU) Komnas Perempuan pada tahun 2019 kasus KDRT di Indonesia terdapat 11.105 kasus. Sedangkan angka perceraian di tahun 2019 meningkat menjadi 416.752 kasus (Komnas Perempuan, 2020). Melihat data tersebut sangat mengkhawatirkan sebagian besar yang menjadi korban adalah perempuan, sehingga diharapkan dengan adanya kebijakan dari pemerintah memberikan perlindungan hukum bagi keluarga terutama 
perlindungan bagi perempuan, dalam upaya menekan jumlah perceraian maupun kasus KDRT di Indonesia.

Program ketahanan keluarga diharapkan menjadi solusi terhadap permasalahan keluarga tersebut. Namun, belum saja disahkannya undang-undang tersebut, justru menimbulkan kontroversi dikalangan masyarakat. Hal itu dikarenakan pasal-pasal yang ada didalamnya dapat menimbulkan ketidakadilan gender. Salah satu permasalahan pada RUU ketahanan keluarga terkait dengan pengaturan peran dan fungsi laki-laki dan perempuan di dalam keluarga.

Persoalan gender bukan hanya mencangkup pada perbedaan jenis kelamin antara perempuan dan laki-laki. Namun lebih kearah konstruksi social mengenai perbedaan perempuan dengan laki-laki yang dibangun oleh masyarakat. Hal ini ditegaskan dalam Instruksi Presiden Nomor 9 Tahun 2000 tentang Pengarusutamaan Gender, bahwa "gender merupakan suatu konsep terkait dengan peran dan tanggung jawab laki-laki dan perempuan yang dapat berubah oleh keadaan sosial budaya masyarakat" (Pemerintah RI, 2000). Selarasa dengan Giddens (dalam Sunarto, 2018) gender berkaitan dengan perbedaan psikologis, sosial, dan budaya yang diberikan masyarakat. Bahkan Kerstan (dalam Sunarto, 2018) mengungkapkan bahwa gender dikontruksi secara sosial bukan bersifat biologis. Dari pemaparan tersebut, dapat disimpulkan bahwa gender merupakan perbedaan perempuan dan laki-laki yang dikontruksikan oleh masyarakat, oleh karena itu masyarakat kerapkali mengkategorikan laki-laki dan perempuan berdasarkan sifat yang dimiliki hingga berujung pada pembagian kerja yang dapat menimbulkan ketidakadilan gender.
Permasalahan tentang gender dibahas khusus dalam Sosiologi. Meskipun pembahasannya kerapkali berbenturan dengan nilai-nilai budaya yang sangat kuat khususnya budaya Indonesia yang sangat kental dengan budaya patriarki, hingga rancangan undangundang pun tidak lepas dari budaya tersebut. Kajian tentang RUU ketahanan keluarga pernah dilakukan oleh Mahendradhani (2020) hasil kajiannya yaitu "RUU ketahanan keluarga dinilai terlalu mencampuri urusan pribadi terkait dengan keluarga, perbedaan akan peran serta tanggung jawab dari laki-laki dan perempuan menjadi tantangan dalam perlindungan hak perempuan".

Berdasarkan permasalahan tersebut, sangat penting dikaji terkait dengan pasal-pasal RUU Ketahanan Keluarga. Artikel ini bertujuan untuk menganalisis RUU ketahan keluarga dalam perspektif sosiologi gender. Dengan menganalisis RUU ketahanan keluarga diharapkan menjadi bahan pertimbangan bagi pengampu kebijakan dalam mengambil keputusan untuk memperkuat ketahanan keluarga di Indonesia.

\section{Metode}

Artikel ini menggunakan metode kajian pustaka. Berbagai kajian Pustaka digunakan dalam membahas artikel ini diantaranya menggunakan berbagai referensi dari buku, artikel jurnal, undang-undang, dan berbagai naskah akademik lainnya sehingga dapat mendukung berbagai informasi dalam paparan tulisan ini.

Kajian artikel ini menitikberatkan pada analisis isi RUU ketahanan keluarga dalam perspektif gender, diperkuat dengan berbagai 
hasil kajian Pustaka lainnya yang relevan serta teori yang disajikan dalam perspektif gender.

Penulisan artikel ini menggunakan pedoman penulisan karya ilmiah berupa naskah akademik yang menggunakan tata Bahasa Indonesia yang baik dan benar, sehingga dapat memudahkan pembaca dalam menggali informasi yang disampaikan dalam artikel ini.

\section{Hasil dan Pembahasan}

Keluarga merupakan agen sosialisasi yang paling utama dalam kehidupan individu. Keluarga di anggap dapat melahirkan berbagai individu dengan berbagai macam kepribadian dalam masyarakat. Keluarga bukan hanya menjadi sarana reproduksi keturunan, namun juga melakukan reproduksi sosial dengan melakukan sosialisasi kepada generasi muda tentang: nilai-nilai kehidupan, moral, berakhlak, norma sosial, kepribadian yang baik, sopan santun, berkarakter, dan menaati berbagai aturan di masyarakat. Sebagaimana yang diungkapkan oleh Ahmadi (2009:87) bahwa keluarga merupakan unit terkecil masyarakat sekaligus kelompok kecil dalam masyarakat. Sebagai unit terkecil di masyarakat maka keluarga memiliki berbagai fungsi, tidak hanya sebatas pada fungsi keturunan tetapi terdapat fungsi lainnya, meliputi:

\section{Fungsi Reproduksi}

Manusia pada hakikatnya memiliki tuntutan biologis untuk keberlangsungan hidupnya dalam memperoleh keturunan melalui ikatan perkawinan. Kaitan dengan fungsi keluarga tersebut disebut dengan fungsi reproduksi.

\section{Fungsi Pemeliharaan}

Keluarga berfungsi untuk memelihara anggota lainnya agar dapat terhindar dari berbagai gangguan baik dari dalam maupun luar keluarganya.

3. Fungsi Afektif

Keluarga berfungsi untuk saling mengasihi, menghargai, dan menyayangi satu sama lain.

\section{Fungsi Ekonomi}

Keluarga berfungsi untuk memenuhi kebutuhan hidup, seperti makan, minum, pakaian, termasuk juga kebutuhan akan pendidikan, kesehatan, dan sebagainya.

\section{Fungsi Keagamaan}

Setiap anggota keluarga menjalankan fungsinya untuk memenuhi kewajiban dalam menjalankan perintah Tuhan Yang Maha Esa serta menjauhi segala larangan-Nya.

\section{Fungsi Sosialisasi}

Keluarga memiliki fungsi mengenalkan nilai norma serta aturan yang ada dalam kehidupan masyaraka, serta berfungsi untuk menjalankan peran-peran yang nantinya akan di jalankan ketika terjun di masyarakat. Terdapat berbagai fungsi-fungsi keluarga lainnya yang perlu dimiliki oleh anggota keluarga.

Jika fungsi-fungsi tersebut dijalani dengan baik oleh semua anggota keluarga tanpa memandang perbedaan fungsi anggota keluarga laki-laki dan perempuan. Bahkan keluarga menjadi agen sosialisasi gender. Sebagaimana yang dijelaskan Sunarto (2018) bahwa keluarga sebagai agen sosialisasi gender atau pembelajaran gender yang berlangsung sejak dini oleh masyarakat. Masyarakat melakukan kontruksi tentang perempuan dan laki-laki sehingga terkadang perlakuannya pun berbeda sesuai dengan sudut pandang 
masyarakat menilai tentang perempuan dan laki-laki didalam keluarga.

Didalam keluarga maka yang terpenting adalah keseimbangan tugas dan fungsi laki-laki dan perempuan dalam keluarga, hal ini selaras dengan prinsip yang disampaikan dalam Rancangan Undang-Undang (RUU) Ketahanan Keluarga dalam Pasal 2 berbunyi: "Ketahanan keluarga berasaskan pada keimanan dan ketakwaan; kekeluargaan; kemanusiaan; keseimbangan; keadilan; pencegahan; kemanfaatan; partisipatif; perlindungan; harmonisasi; dan non diskriminatif". Dalam RUU Ketahanan Keluarga terdapat salah satu asas yang perlu ditekankan yaitu mengenai asas non diskriminatif. Asas non diskriminatif merupakan bagian dari asas RUU Ketahanan Keluarga untuk tidak membeda-bedakan perlakuan berdasarkan perbedaan suku, agama, ras, bahasa, agama, golongan, termasuk perbedaan jenis kelamin.

Berdasarkan asas non diskriminatif tersebut ditegaskan bahwa sebagai anggota keluarga tidak boleh melakukan perilaku yang diskriminatif, misalnya dalam keluarga tidak membeda-bedakan kasih sayang anak pertama dengan anak kedua, tidak membeda-bedakan anak perempuan maupun laki-laki yang mendapatkan pendidikan tinggi, serta tidak membeda-bedakan fungsi dan peran anggota keluarga secara diskriminatif.

Pasal 24 Ayat 1 Rancangan UndangUndang Ketahanan Keluarga, menegaskan bahwa "dalam penyelenggaraan Ketahanan Keluarga, setiap suami istri yang terikat dalam perkawinan yang sah memiliki kewajiban yang luhur untuk menegakkan rumah tangga dan membina harmonisasi keluarga". Pasal ini menekankan bahwa suami istri memiliki kewajiban untuk membina keluarga yang harmonis, namun keharmonisan dalam rumah tangga diciptakan oleh pasangan suami istri yang sama-sama memiliki hak dan kewajiban yang dijalani dengan baik sehingga menciptakan keadaan harmonis, artinya pasangan suami istri harus melengkapi satu sama lain.

Pasal 24 Ayat 2 dalam Rancangan Undang-Undang Ketahanan Keluarga yang berbunyi: "Setiap suami istri yang terikat dalam perkawinan yang sah wajib saling mencintai, menghormati, menjaga kehormatan, setia, serta memberi bantuan lahir dan batin yang satu kepada yang lain". Merujuk pada ayat ini, menunjukkan bahwa suami istri berkewajiban untuk saling mencintai, menghormati, menjaga kehormatan, setia, serta memberikan bantuan lahir dan batin. Namun perlu digaris bawahi untuk menunjukkan kriteria tersebut perlu adanya indikator terukur untuk saling mencintai, dan ranah tersebut sudah memasuki kearah privasi individu, karena masalah cinta adalah terkait dengan perasaan atau hati seseorang. Sehingga sangat sulit untuk menentukan membukti kadar kebahagiaan seseorang secara lahir dan batin jika dimasukkan dalam hukum positif atau undang-undang.

Pasal 24 Ayat 3 dalam Rancangan Undang-Undang Ketahanan Keluarga yang berbunyi: "Setiap suami istri memiliki kedudukan dan hak yang seimbang dalam rumah tangga dan pergaulan hidup bersama dalam masyarakat sesuai dengan norma agama, etika sosial, dan peraturan perundangundangan". Berdasarkan pasal tersebut, menekankan bahwa suami dan istri memiliki kedudukan serta hak yang seimbang dalam rumah tangga menekankan pada asas keadilan sehingga tidak ada anggota keluarga yang 
melakukan diskriminasi. Hal ini mendukung pada pasal 2 yang telah dibahas sebelumnya.

Jika pasal-pasal sebelumnya dibahas bahwa suami istri memiliki hak yang seimbang. Maka berbeda halnya dengan pasal Pasal 25 Ayat 1 bahwa kewajiban suami istri sudah dispesifikasikan dalam tugas dan kewajiban masing-masing. Adapaun isi Pasal 25 Ayat 1 RUU Ketahanan Keluarga yang berbunyi: "Setiap suami istri yang terikat perkawinan yang sah melaksanakan kewajiban masing-masing sesuai norma agama, etika sosial, dan ketentuan peraturan perundangundangan". Berdasarkan pasal 25 ayat 1 tersebut ditegaskan bahwa suami istri memiliki kewajiban masing-masing yang harus dijalani dalam kehidupan rumah tangga. Hal itu berbanding dengan pernyataan pada pasal 24 ayat 3 yang menegaskan bahwa suami istri memiliki kedudukan dan hak yang seimbang dalam menjalani kehidupan rumah tangga. Istilah seimbang dapat diartikan dengan setara, sama, atau sebanding. Sehingga persepsi pasalpasal tersebut bisa saja berbeda. Apalagi dipertegas dengan adanya ayat selanjutnya yang lebih memperkuat perbedaan kewajiban suami dan istri.

Pasal 24 Ayat 2 Rancangan UndangUndang Ketahanan Keluarga, menjelaskan bahwa: "Kewajiban suami sebagaimana dimaksud dalam ayat (1), antara lain: a. Kepala Keluarga yang bertanggung jawab untuk menjaga keutuhan dan kesejahteraan keluarga, memberikan keperluan hidup berumah tangga sesuai dengan kemampuannya, dan bertanggung jawab atas legalitas kependudukan keluarga; b. Melindungi keluarga dari diskriminasi, kekejaman, kejahatan, penganiayaan, eksploitasi, penyimpangan seksual, dan penelantaran; c.
Melindungi diri dan keluarga dari perjudian, pornografi, pergaulan dan seks bebas, serta penyalahgunaan narkotika, alkohol, psikotropika, dan zat adiktif lainnya; serta d. Melakukan musyawarah dengan seluruh anggota keluarga dalam menangani permasalahan keluarga".

Berdasarkan RUU Pasal 25 ayat 2 tersebut, suami memiliki kewajiban yang difokuskan sebagai kepala rumah tangga, memiliki kewajiban dalam mencari nafkah, memberikan perlindungan bagi anggota keluarga dari diskriminasi, melindungi dari perbuatan yang menyimpang, serta melakukan musyawarah dalam upaya menyelesaikan permasalahan. Dalam aturan tersebut, terdapat gambaran bahwa fungsi keluarga seperti fungsi perlindungan serta fungsi ekonomi hanya dititik fokuskan pada kewajiban ayah. Padahal jika melihat dari fungsi-fungsi keluarga seperti reproduksi, perlindungan, ekonomi, keagamaan, afeksi, dan fungsi lainnya dijalani oleh pasangan suami istri, bukan hanya menitikberatkan pada kewajiban seorang individu saja. Pasal 25 ayat 2 melegalkan budaya patriarki yang mengutamakan laki-laki dalam kehidupan keluarga. Ketika peran suami sebagai ordinat dikedepankan sedangkan peran istri dianggap hanya sekedar pelengkap, akan dikhawatirkan sangat rentan terjadi tindak kekerasan dalam rumah tangga.

Hal yang sama dijelaskan pada Pasal 25 Ayat 3 Rancangan Undang-Undang Ketahanan Keluarga, menjelaskan bahwa: "Kewajiban istri sebagaimana dimaksud dalam ayat (1), antara lain: a. wajib mengatur urusan rumah tangga sebaik-baiknya; b. menjaga keutuhan keluarga; serta c. memperlakukan suami dan anak secara baik, serta memenuhi hak-hak suami dan anak sesuai norma agama, etika sosial, dan ketentuan peraturan perundangundangan". Berdasarkan ayat tersebut, tersirat bahwa negara telah mengatur apa yang diwajibkan oleh perempuan seperti mengurus 
rumah tangga, menjaga keutuhan keluarga, serta memperlakukan suami dan anak dengan baik. Penekanan tanggung jawab istri pada ranah domestik.

Pada Pasal 25 ayat 2 dan 3 inilah yang mengandung kontroversi dikalangan masyarakat. Pada pasal ini jelas mengatur kewajiban masing-masing suami dan istri di dalam kehidupan keluarga. Hal tersebut sangat kontradiksi dengan pasal sebelumnya yaitu pasal 2 yang menyatakan bahwa ketahanan keluarga berasaskan keadilan dan non diskriminatif, begitupula dengan pada pasal 24 ayat 3 dimana suami istri memiliki hak dan kewajiban yang seimbang. Jika suami dan istri memiliki kewajiban masing-masing sebagaimana yang ditegaskan dalam pasal 25 ayat 2 dan 3 maka prinsip keadilan, keseimbangan, dan non diskriminatif sulit untuk dihindari.

Rancangan Undang-Undang Ketahanan Keluarga terutama pada pasal 25 menggambarkan bahwa negara mengatur pada ruang privat dan spiritual masyarakat. RUU Ketahanan Keluarga mengatur tentang kewajiban dan peran penting suami dan istri serta orangtua dan anak didalam keluarga. Dalam suatu keluarga terkadang berbeda dengan kondisi keluarga lainnya tidak bisa diseragamkan, sehingga tolak ukur untuk menjalani peran dan kewajiban tentunya berbeda, serta konsekuensi terhadap pelanggaran jika tidak menjalani kewajiban belum dapat terukur. Nyatanya tidak semua masyarakat memiliki peran-peran yang sama sebagaimana yang ditegaskan dalam pasal 25 ayat 2 dan 3, sebagai contoh kasus terdapat suami yang justru memilih untuk mengurus rumah tangga sedangkan istri justru yang mencari nafkah, jika hal tersebut terjadi apakah dapat dikategorikan sebagai pelanggaran hukum?. Pasal ini dapat menunjukkan ketidakadilan gender karena membedabedakan peran dan fungsi laki-laki dan perempuan.
Menurut Darvina (2010: 2.3) ketidakadilan gender merupakan suatu sistem maupun struktur dimana laki-laki maupun perempuan dapat menjadi korban dari sebuah sistem, sistem dibentuk dari persepsi masyarakat mengenai perbedaan gender. Akibat dari sistem tersebut perempuan memiliki keterbatasan dalam mengakses halhal yang penting bagi hidupnya termasuk Pendidikan, Kesehatan, keadilan dimata hukum, dan sebagainya. Hal itu dikarenakan perempuan dianggap sebagai subordinat atau pelangkap bagi laki-laki, sedangkan laki-laki dianggap memiliki peran utama atau ordinat. Hal tersebut selaras dengan ketentuan pasal 25 ayat 2 bahwa laki-laki yang berhak mengembil keputusan dalam menyelesaikan masalah keluarga. Menurut Remiswal (2013:14) dalam "teori struktural fungsionalisme menyatakan bahwa masyarakat akan stabil bila unsur pembentuknya terintegrasi dalam sistem maka dari itu laki laki dan perempuan sebagai bagian dari masyarakat harus berperan sesuai fungsinya". Jika mengacu pada teori struktur fungsional maka secara sistem seharusnya perempuan dan laki-laki dapat menjalankan hak dan kewajibannya secara seimbang, sehingga dengan begitu akan melahirkan keluarga yang harmonis.

Tuntutan di zaman saat ini, mengharuskan perempuan untuk mendapatkan pendidikan tinggi sehingga menjadikan perempuan lebih mandiri dengan bekerja diluar rumah, bukan hanya berperan dalam sektor domestik tetapi perempuan dapat bekerja disektor formal dengan memainkan peran ganda baik sebagai pekerja, sebagai ibu, sebagai istri, dan sebagainya. Sehingga tuntutan kewajiban suami istri bisa saja berubah sesuai dengan komitmen pasangan suami istri untuk menentukan perannya di dalam keluarga.

Pasal Rancangan Undang-Undang Ketahanan tidak semuanya mengandung kontroversi, bahkan terdapat pasal yang justru 
memperhatikan perempuan pekerja dalam pasal 29, pasal ini seolah kontradiksi dengan pasal 25 ayat 2 yang memberikan pandangan bahwa perempuan bekerja di sector domestik. Pasal 29 Ayat 1 Rancangan Undang-Undang Ketahanan Keluarga menyebutkan bahwa: "Pemerintah wajib memfasilitasi istri yang bekerja untuk mendapatkan hak cuti melahirkan dan menyusui selama 6 (enam) bulan, tanpa kehilangan haknya atas upah atau gaji dan posisi pekerjaannya”. Pada pasal 29 ayat 1 dapat disimpulkan bahwa perempuan memiliki hak untuk bekerja dan tetap menjalani kodratnya sebagai seorang ibu yang mengandung, melahirkan, dan menyusui anakanaknya dengan diberikan dispensasi cuti melahirkan selama 6 bulan tanpa pemotongan gaji. Meskipun perempuan memiliki kesempatan bekerja di sector formal, namun partisipasi perempuan masih rendah untuk mendapatkan kedudukan strategis dalam pekerjaan.

Selain pengaturan tentang cuti melahirkan, RUU ketahanan keluarga juga mengatur tentang larangan jual beli sperma dan ovum yang terdapat Pasal 31 (1) dan (2). Serta Pasal 139 dan 140 tentang sanksi yang melanggar pasal 31. Sebelum adanya RUU ketahanan keluarga, aturan tentang larangan donor ovum sudah terdapat dalam UndangUndang Nomor 36 Tahun 2009 tentang Kesehatan. Ditegaskan dalam Pasal 2 UndangUndang Nomor 36 Tahun 2009 tentang Kesehatan yang "berlandaskan pada perikemanusiaan, manfaat, pelindungan, keseimbangan, keadilan, gender, penghormatan terhadap hak dan kewajiban, dan nondiskriminatif serta sesuai dengan norma-norma agama" (Pemerintah RI, 2009). Dalam menjalankan fungsi keluarga untuk memperoleh keturunan dengan melihat asas gender dan nondiskriminatif, artinya tidak membedakan-bedakan perlakuan terhadap perempuan dan laki-laki karena bisa saja dalam pasangan suami istri ada yang tidak memiliki kesuburan sehingga sulit mendapatkan keturunan, sehingga melakukan berbagai cara untuk memperoleh keturunan. Mekipun tujuannya baik, namun perlu adanya kajian ulang mengenai pasal tersebut agar tidak memasuki ranah privasi.

Dalam mengambil kebijakan pemerintah sudah seharusnya dapat lebih memprihatikan peran perempuan. Seyogyanya perempuan sangat berperan dalam pembangunan bangsa Indonesia. Menurut Ihromi (2004: 166) wanita memiliki peran penting di dalam penentuan arah pembangunan, peranan tersebut terkait dengan keluarga. Wanita merupakan tokoh yang sangat penting dilingkungan keluarga, bahkan ibu menjadi awal pendidikan pertama dan utama seorang anak. Oleh karena itu, keadilan gender bagi perempuan perlu dikedepankan diranah domestik maupun publik. Sebagaimana yang dijelaskan oleh Remiswal (2013:16) gender merupakan kesederajatan peran manusia dalam masyarakat, dimana laki laki dan perempuan memiliki akses dan kesempatan yang sama, tidak dibenarkan jenis kelamin tertentu memutus hak jenis kelamin lainnya, memberikan penghargaan terhadap peran yang dijalani masing masing, kesederajatan peran melingkupi wilayah domestik maupun publik".

Menurut Tsalatsa (dalam remiswal, 2013) mengungkapkan beberapa hak hak yang menjadi tuntutan perempuan atas laki laki.

1. Hak-hak sipil

Hak-hak sipil meliputi kebebasan dari perlakuan yang kejam dan tidak manusiawi, hak atas keamanan, kedudukan serta perlakuan yang sama di mata hukum. 


\section{Hak-hak Politik}

Setiap masyarakat berhak untuk memiliki kebebasan berfikir, menyatakan pendapat berpartisipasi dalam pemerintahan, hak untuk berserikat dan berkumpul. Di Indonesia keterwakilan perempuan dalam pengambilan keputusan sebesar 30\%.

3. Hak-hak sosial ekonami

Hak-hak sosial ekonami meliputi hak unutuk memperoleh pekerjaan yang layak, hak untuk memperoleh keadilan, hak untuk sehat, hak atas jaminan sosial, hak memperoleh pendidikan.

4. Hak-hak Budaya

Hak budaya meliputi hak yang sama dalam menjalankan tradisi budaya yang ada dimasyarakat. Termasuk hak-hak lainnya yang sama didapatkan misalnya hak kesempatan mengenyam pendidikan tinggi, hak akan kesehatan, hak mendapatkan perlindungan serta keadilan dimata hukum, hak hidup sejahtera, dan sebagainya.

Pemerintah sebagai pengampu kebijakan dapat memberikan ruang kepada perempuan agar berkontribusi dalam pembangunan. Salah satu indikator dari pembangunan yaitu kesetaraan gender. Sehingga perempuan dapat diikutsertakan dalam proses politik, ekonomi, hingga pengambilan keputusan di pemerintahan. Menurut Setiadi (2010: 902) terdapat pendekatan pembangunan bagi perempuan sebagai berikut:

1. Pendekatan kesejahteraan

Memberikan bantuan keterampilan bagi perempuan untuk meningkatkan kesejahteraan keluarga.

2. Pendekatan keadilan

Mengurangi ketidakadilan antara lakilaki dan perempuan, terutama pembagian kerja dan pemenuhan kebutuhan strategis gender.

\section{Pendekatan anti kemiskinan}

Meningkatkan produktivitas perempuan dirumah tangga sehingga dapat berpenghasilan dengan membuka sumber-sumber ekonomi.

4. Pendekatan efisiensi

Peningkatan partisipasi perempuan akan berdampak menciptakan keadilan dan kesetaraan gender. Oleh karena itu, partisipasi perempuan dapat menentukan keberhasilan pembangunan.

5. Pendekatan penguatan diri

Memberikan penguatan kepada perempuan untuk berpartisipasi dalam pembangunan sehingga perempuan dapat berkontribusi didalam masyarakat.

Keberadaan partisipasi perempuan dalam pembangunan seolah kontradiksi dengan isi pasal 25 ayat 3 yang hanya melihat perempuan dalam sektor domestik. Hal ini justru berbeda dengan Instruksi Presiden Nomor 9 Tahun 2000, menyatakan bahwa "keseteraan gender merupakan kesamaan kondisi baik antara laki-laki maupun perempuan dalam memperoleh kesempatan yang sama dan memiliki hak yang sama sebagai manusia, sehigga mampu berperan dan berpartisipasi dalam kegiatan politik, sosial budaya, ekonomi, dalam upaya pertahan dan keamanan nasional, serta kesamaan dalam menikmati hasil pembangunan bangsa" (Pemerintah RI, 2000). Berdasarkan aturan tersebut, maka sangat jelas bahwa pemerintah telah mengatur mengenai kesetaraan gender antara laki-laki dan perempuan baik dalam kehidupan keluarga, bermasyarakat, berbangsa dan bernegara.

RUU Ketahanan Keluarga mengatur tentang kewajiban suami dan istri, hal ini dianggap bertentangan dengan kebijakan sebelumnya terkait dengan Instruksi Presiden Nomor 9 Tahun 2000 tentang 
Pengarusutamaan Gender, menyatakan bahwa keseteraan gender merupakan kesamaan kondisi baik antara laki-laki maupun perempuan dalam memperoleh kesempatan yang sama dan memiliki hak yang sama sebagai manusia (Pemerintah RI, 2000). Berdasarkan aturan tersebut, maka sangat jelas bahwa pemerintah telah mengatur mengenai kesetaraan gender antara laki-laki dan perempuan baik dalam kehidupan keluarga, bermasyarakat, berbangsa dan bernegara.

Aturan lainnya yang mendukung terkait dengan Agenda Internasional tahun 2030 untuk melakukan "Pembangunan Berkelanjutan" Sustainable Development Goals atau SDGs (2015), kebijakan ini menjunjung tinggi kesetaraan gender dengan menghilangkan diskriminasi, kekerasan terhadap perempuan, mendapatkan kesempatan yang sama, memperkuat kebijakan mengenai kesetaraan gender, dan aturan lainnya. Dengan kebijakan tersebut, maka komitmen untuk memperjuangan kesetaraan gender di Indonesia perlu dijunjung tinggi, jangan sampai mengalami tumpang tindih dengan kebijakan yang ada.

Hal tersebut selaras pendapat dari Komnas Perempuan (2011) bahwa sejumlah undang-undang nasional masih bias gender bahkan diskriminatif terhadap perempuan. Bahkan data yang dilansir dari Komnas Perempuan terdapat 63 atau $61 \%$ peraturan yang melanggar hak perempuan, ditunjukkan dalam gambar1, sebagai berikut:

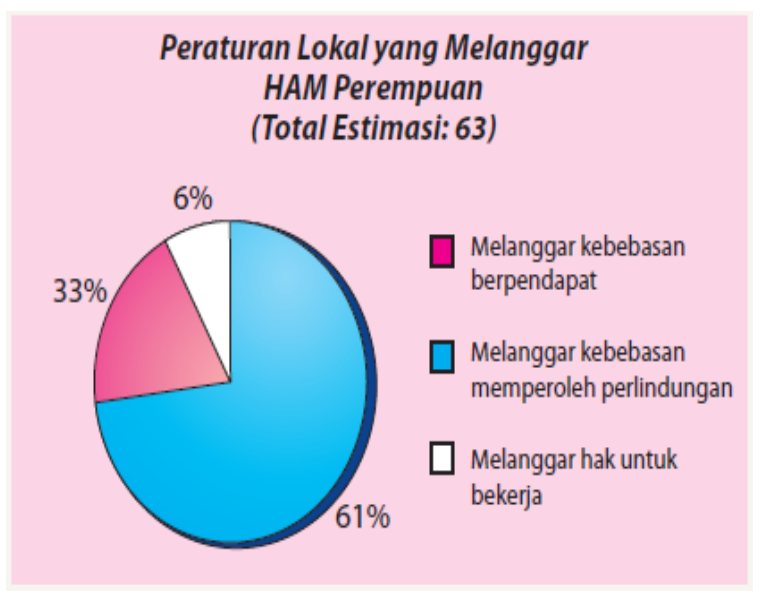

Sumber: Komnas Perempuan, 2011

Gambar 1. Kebijakan yang Melanggar HAM Perempuan

Berdasarkan gambar 1, bahwa seharusnya kebijakan yang diambil baik oleh pemerintah daerah maupun pusat perlu memperhatikan kesetaraan gender, dimana perempuan memiliki hak yang sama dalam aturan hukum maupun aturan kebijakan. Sehingga dengan adanya RUU Ketahanan Keluarga yang menimbulkan kontroversi karena pasal yang ada didalamnya mengandung ketidakadilan gender. Sebagaimana yang diungkapkan oleh Rahmawati, N., \& Muslichatun, M. (2020) Rancangan Undang-undang (RUU) Ketahanan Keluarga perlu dikaji ulang agar tidak menimbulkan polemik yang berkelanjutan di kalangan masyarakat. Masih banyak permasalahan yang perlu diatur di dalam RUU agar dapat dijadikan UU secara resmi dan tetap memperhatikan HAM. Hal ini selaras dengan Dewanti (2020) RUU Ketahanan Keluarga bertolakbelakang dengan kesetaraan gender, dimana terdapat diskriminasi terhadap perempuan bahkan memundurkan perjuangan perempuan. 
Sedangkan pendapat lainnya diungkapkan oleh Mahendradhani (2020) hasil kajiannya menyatakan bahwa "RUU ketahanan keluarga dinilai terlalu mencampuri urusan pribadi terkait dengan keluarga, perbedaan akan peran fungsi serta tanggung jawab dari pasangan, serta menjadi tentangan dalam perlindungan hak perempuan". Selaras dengan kajian sebelumnya menurut hasil kajian yang dilakukan oleh Aji, R. H. S. (2020) Rancangan Undang-Undang Ketahanan Keluarga memiliki tujuan memperkokoh ketahanan keluarga di Indonesia, namun keberadaan RUU Ketahanan Keluarga bernuansa politik karena pasal-pasal yang ada didalamnya mengabaikan nilai-nilai emansipasi perempuan.

Komnas Perempuan (2020) memberikan sikap dengan membuat pernyataan bahwa usulan RUU Ketahanan Keluarga tidak dibutuhkan, dengan salah satu pertimbangan melakukan peninjauan ulang terkait dengan perlindungan namun tidak didasari pada pemahaman mengenai kekerasan dan diskriminasi berbasis gender yang akan menghalangi terwujudnya keadilan dan kesetaran gender".

Berdasarkan hasil kajian-kajian yang telah dijelaskan, maka usulan RUU Ketahanan keluarga perlu dikaji ulang agar tidak melahirkan diskriminasi terhadap perempuan serta dapat mewujudkan keadilan gender.

Meskipun pasal-pasal didalamnya mengandung polemik, namun pada dasarnya RUU Ketahanan Keluarga memiliki tujuan yang baik untuk memperkuat ketahanan keluarga. Jika dilihat dari kajian landasan sosiologis terkait dengan pengaturan Ketahanan Keluarga yaitu; keluarga sebagai bagian unit kecil masyarakat merupakan modal dasar sebagai basis dan titik sentral kegiatan pembangunan nasional serta ketahanan keluarga merupakan pilar utama dalam mewujudkan ketahanan nasional. Sebagaimana yang diungkapkan oleh Muthmainnah (2020), RUU ketahanan keluarga membahas aspek sosiologis dimana keberadaan keluarga menjadi pranata sosial yang sangat penting dalam membentuk individu sebagai unit terkecil dalam suatu bangsa, RUU ketahanan keluarga sebagai bentuk ketahanan negara dalam menonjolkan peran penting keluarga.

Sosiologi mengkaji keberadaan RUU ketahanan keluarga dilatarbelakangi adanya perubahan sosial di masyarakat Indonesia yang sulit dihindari. Terjadi di bidang kehidupan seperti bidang sosial, pendidikan, ekonomi, budaya serta teknologi informasi, dan berbagai bidang lainnya. Keberadaan perubahan sosial tersebut menggesar tatanan keluarga, sehingga diperlukan kebijakan Ketahanan Keluarga yang berpihak pada kepentingan keluarga dan mampu memberikan perlindungan kepada keluarga dari pengaruh globalisasi yang negatif khususnya bagi generasi penerus bangsa yang mudah terkontaminasi dengan budaya luar yang negatif. Maka keluarga diharapkan menjadi filter utama maupun sebagai proteksi dari bahaya yang ditimbulkan. Berdasarkan kajian itulah dirasa penting Undang-Undang Ketahanan Keluarga dihadirkan namun perlu yang perlu ditekanan dalam RUU Ketahanan perlu adanya pengkajian pasal-pasal tertentu agar implementasi Undang-Undang tetap mengedepankan keadilan gender maupun hak asasi manusia perempuan di Indonesia.

Implikasi dari artikel ini dapat menjadi bahan pertimbangan pengampu kebijakan dalam mengambil keputusan dalam mengesahkan Rancangan Undang-Undang Ketahanan Keluarga di Indonesia dengan 
catatan melakukan pengkajian ulang terhadap pasal-pasal yang memicu timbulnya ketidakadilan gender dan diskriminasi terhadap perempuan. Dengan adanya payung hukum tentang keluarga diharapkan dapat menjadikan keluarga masyarakat Indonesia yang harmonis serta berkualitas, sehingga dapat dengan mudah mewujudkan ketahanan keluarga yang nantinya akan menjadi pedoman utama terwujudnya ketahanan nasional.

\section{Kesimpulan}

Rancangan Undang-Undang (RUU) dilatarbelangi dengan adanya perubahan social yang terjadi pada masyarakat Indonesia yang rentan mengalami penyimpangan sosial akibat pengaruh budaya global yang tidak sesuai dengan budaya bangsa. Ketahanan Keluarga bertujuan untuk memperkuat ketahanan keluarga masyarakat Indonesia. Rancangan Undang-Undang Ketahanan Keluarga menjadi polemik di kalangan masyarakat. Salah satu permasalahan pada RUU Ketahanan Keluarga termaktub dalam pasal 25 ayat 2 dan 3 yang membahas tentang peran dan fungsi perempuan dalam keluarga.

Artikel ini bertujuan untuk menganalisis RUU ketahan keluarga dalam perspektif sosiologi gender. Penulisan artikel ini menggunakan metode kajian literatur yang berasal dari buku, jurnal, dokumen lain yang relevan untuk mengkaji permasalahan dalam RUU Ketahanan keluarga dalam perspektif sosiologi gender.

Hasil kajian ini menunjukkan bahwa Rancangan Undang-Undang ketahanan keluarga mengandung pasal yang dapat menimbulkan kotroversi di masyarakat terutama tentang hak dan kewajiban suami maupun istri yang dapat menimbulkan ketidakadilan gender, perempuan memiliki kewajiban bekerja pada ranah domestik, sedangkan laki-laki berperan dalam pengambilan keputusan. Peraturan tersebut kontradiksi dengan Sustainable Development Goals atau SDGs yang mengedepankan kesetaraan gender dan menghapuskan diskriminasi. Serta bertentangan dengan Instruksi Presiden Nomor 9 Tahun 2000 tentang Pengarusutamaan Gender.

Ketahanan keluarga memiliki tujuan baik untuk memperkuat ketahanan keluarga sebagai upaya mewujudkan ketahanan bangsa, namun perlu dikaji lebih mendalam tentang pasal-pasal yang ada di dalam Rancangan Undang-Undang Ketahanan Keluarga agar tetap mengedepankan keadilan gender di Indonesia.

\section{Referensi}

Aji, R. H. S. 2020. Masih Relevankah Gagasan Emansipasi Perempuan Kartini? Tinjauan atas RUU Ketahanan Keluarga. 'ADALAH, 4(4).

Ahmadi, A. 2009. Ilmu Sosial Dasar. Jakarta: Rineka Cipta.

Darvina, V. S \& Sulistyowati, T. 2010. Sosiologi Gender. Jakarta: Universitas Terbuka.

Dewanti, A. K. 2020. Kontroversi RUU Ketahanan Keluarga. Arsip Publikasi Ilmiah Biro Administrasi Akademik.

Dewan Perwakilan Rakyat. 2020. Naskah Akademik RUU Ketahanan Keluarga. Diakses dari http://www.dpr.go.id/dokakd/dokumen, pada 27 Februari 2020.

Dewan Perwakilan Rakyat. 2020. RUU Ketahanan Keluarga. Diakses dari http://www.dpr.go.id/dokakd/dokumen/ RJ2-20200214-122745-3039.pdf, pada 27 Februari 2020. 
Ihromi, T. 2009. Bunga Rampai Sosiologi Keluarga. Jakarta: Yayasan Obor Indonesia.

Komnas Perempuan. 2011. Kertas Kebijakan

Kesetaraan Gender. Diakses dari http://documents1.worldbank.org, pada 27 Februari 2020.

Komnas Perempuan. 2020. Pernyataan Sikap Komnas Perempuan tentang Polemik RUU Ketahanan Keluarga. Diakses dari https://www.komnasperempuan.go.id, pada tanggal 27 Februari 2020.

Komnas Perempuan. 2020. Catatan Kekerasan Dalam Rumah Tangga Tahun 2019. Diakses dari https://www. Komnas perempuan .go.id, pada 6 Maret 2020.

Mahendradhani, G. A. A. R. 2020. Analisis Kritis Terhadap Rancangan UndangUndang Kritis Terhadap Rancangan Ketahanan Keluarga Terkait dengan Kemandirian Perempuan. Vyvahara Duta, 15(1), 43-50.

Muthmainnah, M. 2020. RUU Ketahanan Keluarga: Modifikasi Hukum Sebagai Upaya Mencapai Tujuan Hukum Islam Dalam Memelihara Keturunan. Journal of Islamic Law Studies, Sharia Journal, I(2).

Pemerintah Republik Indonesia. 2000. Instruksi Presiden Republik Indonesia Nomor 9 Tahun 2000 Tentang Pengarusutamaan Gender dalam pembangunan Nasional. Diakses dari http://pugpupr.pu.go.id/_uploads/PP/Inpr es_No.9Thn_2000, pada 27 Februari 2020.

Pemerintah Republik Indonesia. 2009. Undang-Undang Nomor 36 tahun 2009 tentang Kesehatan. Diakses dari infeksiemerging.kemkes.go.id, pada tanggal 27 Februari 2020.

Rahmawati, N., \& Muslichatun, M. 2020. Tinjauan RUU Ketahanan Keluarga Tentang Larangan Jual Beli dan Donor Sperma Ovum dalam Perspektif Hukum Pidana. Lontar Merah, 3(1), 267-280.

Remiswal. 2013. Mengunggah Partisipasi Gender di Lingkungan Komunitas Lokal. Yogyakarta: Graha Ilmu.

Sunarto, K. (2018). Pengantar Sosiologi. Jakarta: Lembaga Penerbit Fakultas Ekonomi Universitas Indonesia.

Setiadi, E. M \& Kolip, U. 2010. Pengantar Sosiologi Pemahaman Fakta dan Gejala Permasalahan Sosial Teori, Aplikasi, dan Pemecahannya. Jakarta: Kencana.

Sustainable Development Goals. (2015). Diakses dari https:// www.sdg 2030 indonesia.org, pada 27 Februari 2020. 


\section{Biarkan halaman ini tetap ada}

[ halaman ini sengaja dikosongkan ] 